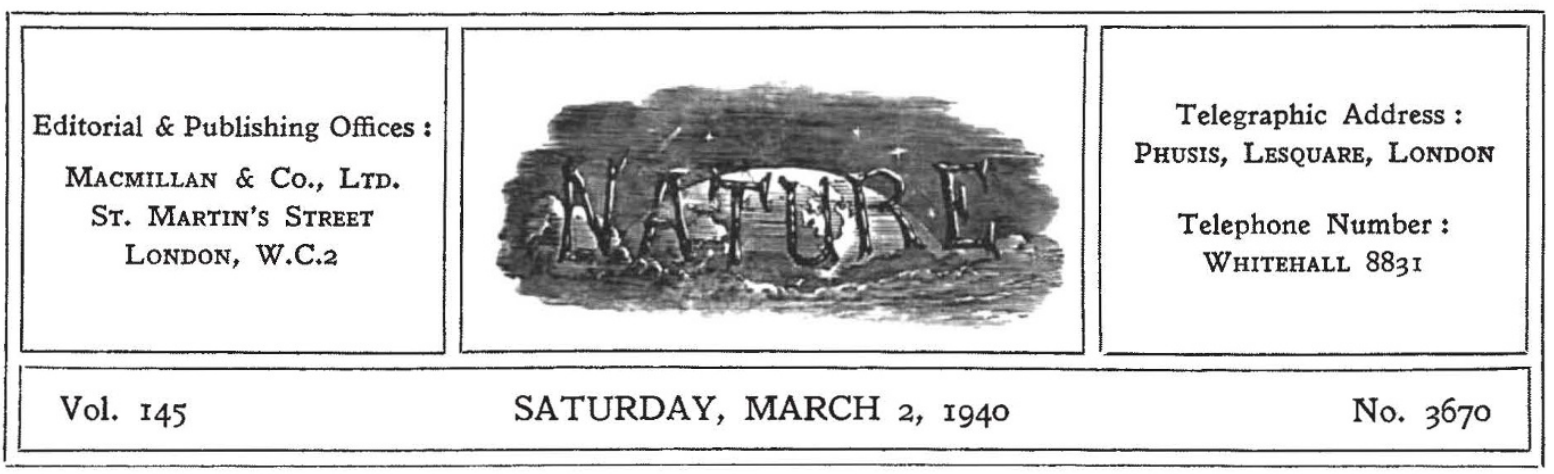

\title{
THE UNIVERSITIES IN WAR-TIME
}

$\mathrm{T}$ HE function of the universities in relation to research needs in war-time may not be so well appreciated as other factors which at the present time are directing attention to their place in the national life of Great Britain. Like other educational institutions, their work has in many places been seriously disturbed by the exigencies of evacuation. Both research and teaching have been interrupted, and even where satisfactory and efficient arrangements have been made in the reception areas for the performance of those functions, great difficulties have frequently been met by students. These difficulties, for example, have deprived University College, London, and the London School of Economics of half their students. Although a number of evacuated university institutions are now expected to return to their normal quarters by the autumn term, there is sound reason in the appeal of the National Union of Students for a Government grant to enable students who would otherwise be deprived of their education to continue their studies.

The attempt to return to normal education and to evolve a sound and practical policy out of the muddle into which evacuation has thrown it must include university education along with the elementary and secondary stages. In contrast to 1914, the universities have indeed already been recognized by Government as institutions of national importance, both from the point of view of assisting in the War, and also of maintaining higher learning and culture. The welcome news that the Government has decided to maintain its Treasury grant at the pre-War level (see NATURE, February 24, p. 299), strengthens this conviction. In the contacts of the past year or so between the universities and the Service and other Government departments in regard to the utilization of personnel and facilities, and particularly in the sympathy and understanding which characterize this co-operation, we have evidence that the role of the universities in supplying the educated and trained leadership essential in handling the problems of a democratic society is fully appreciated by the Government.

If therefore it is admitted that universities are vital necessities in the efficient service of the needs of a democratic society, whether as an industrial nation in a world where science is the basis of power, or in the defence of its life, its liberties and traditions against the methods of modern warfare, it can scarcely be disputed that a grave responsibility must rest on the universities in the preservation of the permanent values of our ordinary life. The autonomy of government, the freedom of speech and thought and investigation which are cherished privileges of British universities, place upon them a prime responsibility to provide the informed and disciplined intelligence that alone can be adequate to meet the needs of a post-War world, to repair the breaches made in our institutions by the War, and to reconstruct those parts of our political and economic system which are shown to be defective by the War. If reconstruction is to have a practical meaning, it requires at once the trained and disciplined in. telligence, the impartial and patient analysis, the imaginative insight on human issues, the sense of values and creative force which it should be a chief glory of our universities to supply.

The importance of the contribution which the universities can make to the winning of the War, to the planning of the peace and the provision of 
leadership of the requisite capacity, makes it essential that the ways and means by which that contribution is made should be rigorously reexamined. It is no simple problem to secure the economy that may justly be demanded, without endangering the deeper values which a university must always safeguard. The Treasury grants to the universities have always recognized the right of the universities to enjoy complete freedom. In war-time, that independence must be preserved at all costs. Nothing is easier than for the essential liberties for which we are contending to be endangered and lost by gradual encroachment under the duress of war.

Unsleeping vigilance in these matters is essential, but the universities must prove themselves worthy of that independence by the thoroughness of their response to the national need, and the ability with which they not only maintain their highest traditions but also raise the efficiency of their service. On the economic side there are things with which they can do without, and without which they will be content. They will not expect the same funds for new buildings which in better times they ought to have. It is not in war-time that we can expect most of our modern universities to approach nearer to the Platonic ideal that youth should be brought up "amid fair sights and sounds".

The essentials of university education must not be stinted. Municipal bodies, like the State, should continue their help at least undiminished, increasing it where those essentials are lackingor inadequately provided. Even in war-time, it is a good investment for the nation to provide at the modern universities more opportunities for healthy recreation as a part of the corporate life. The Physical Education Centre which the University of Manchester has recently opened is a token of the movement to make the life of the modern university more rounded and complete. Behind that movement, moreover, lies the possibility of developing a system of physical education which will make the student's life happier and more efficient in the best sense ; and there is a large field for research, the knowledge garnered from which may be applied not only to university students but also to adolescents generally.

Here is only one of the directions in which the universities might, even in war-time, extend their services to the community. There is also a great task in extra-mural work, which some of them are already shouldering, despite all the handicaps imposed by the black-out. Programmes of lectures are being provided for troops in the areas served by the universities in an attempt to see that the minds of those called to the colours do not stagnate or become set in Service grooves. In spite, too, of the dislocation of civil life and the long hours put in on munitions, the demand for tutorial classes is strong, and the teaching normally done outside the universities on their own initiative or in collaboration with the Workers' Educational Association proceeds vigorously.

The significance of this extra-mural work should not be under-rated. As Dr. W. C. Mitchell reminds us in his presidential address to the American Association for the Advancement of Science (see Nature of February 10, p. 207) the gravest dangers to democracy come from within, not from without. The universities have a decisive part to play in dispelling ignorance and countering by critical inquiry the propaganda which turns ignorance to its uses. In war as in peace, those who cherish learning must seek to foster, by all means within their power, a scientific attitude among their fellow citizens. Extra-mural work offers an invaluable opportunity of developing respect for evidence and promoting a general understanding of the methods and results of science.

Important as may be the educational functions of the universities in such extra-mural fields, it is to the training given within their walls and to their functions in the advancement of knowledge and the maintenance of standards that attention is at present being most cleárly directed. The pursuit of knowledge and the training of youth must indeed go hand in hand with the cherishing of human values-of personality, of freedom and truth-if a university is to make its full contribution to the enrichment of national life, above all by inspiring that deep consciousness and apprecia. tion of the national heritage which alone can sustain the effort and sacrifices which their defence may well demand in the present struggle. What. ever resources may be available for the universities -and the importance of their contribution to our war effort and the preservation of the permanent values of our heritage may well justify expansion rather than contraction of those resources-the present position demands that they should be used as wisely and efficiently as possible.

It is from this point of view that it is imperative to re-examine the utilization of these resources and their distribution over the various functions of a university and the numerous branches of learning 
which it serves. Let no one imagine that this is a simple task. The complexity of the relations between the different functions and faculties must not deter us from the task, and the gravity of the danger which threatens all alike may well be sufficient at last to initiate the effort.

In regard to the advancement of learning, the university occupies a place in the research front. If knowledge is to be available to serve the wartime needs of the nation no less than to solve the problems of peace, some means must be found of keeping an appropriate balance between fundamental and applied research, of providing for the following-up of advances in knowledge, and of diverting effort to fields neglected or holding up the general advance. All this must be done without endangering that freedom of investigation and spirit of unprejudiced quest for truth which lie at the root of all scientific advance. Particularly is it important to provide for investigations in the domain of human relations, where lack of knowledge is already handicapping our war effort in many fields.

The advancement of knowledge links itself naturally with the teaching functions of the university through the thorny problem of the relation of teaching and research. Here we may well have to review the whole question of technique in the light of recent criticism and discussion on the use of the lecture or the tutorial system. Similarly, we have to consider the efficiency of research at the universities, not merely in terms of the claims of teaching, tutorial or administrative duties, but also in regard to the provision of adequate assistance or services in the laboratories, so that the best use is made of the time of qualified research workers.

These are questions which, like those of professional training, may well occupy the attention of the universities themselves and also of the many professional associations of scientific workers and their fellows. We cannot expect in the stress and strain of war to find and apply a completely satisfactory solution to them all. We may indeed need to be content with eliminating major causes of inefficiency and securing a modicum of co-operation in the pursuit of knowledge where it is most required. If, however, scientific and professional workers, whether within the walls of a university or without, are zealous enough in cherishing a high ideal of the functions of a university and give their minds, even in war-time, to such problems as these, then at least we may be sure that the universities of Great Britain will carry undimmed through these dark days their power to inspire, and to provide the loyal and unselfish leaders the nation needs both now and in the days of reconstruction to come.

\section{CANCER: THE ROLE OF SURGERY, RADIUM AND $X$-RAYS IN ITS TREATMENT}

$\mathrm{T}$ $\mathrm{HE}$ treatment of cancer has occupied an increasingly important position in public thought during the last few years. The debate in Parliament on the Cancer Bill laid bare the scanty provisions for adequate treatment existing in many parts of Britain. The war crisis in September which temporarily curtailed medical facilities resulted in an insistent demand for the treatment of cancer, a demand not immediately heard for the treatment of most other diseases. One aspect of this interest is the difference of opinion as to the proper scope of radium treatment relative to other methods, a difference illustrated by recent and present correspondence in NATURE $(144,973 ; 1939 ; 145,151 ; 1940$; also p. 347 of this issue).

Before attempting an assessment of the present status of cancer treatment, it will be instructive to examine first the extent to which cancer is in fact being treated in Great Britain at the present time, and the means available. A recent Ministry of Health inquiry* showed that in a representative sample 27 per cent of all cases were actually treated by either surgery or radiation, including purely palliative treatment. Allowing for possible groups of cases not coming into the sample, it is safe to say that less than 30 per cent of all cases occurring receive treatment. As to the means available, there are only two by which successful cure of cancer can be achieved-surgical excision and radium or X-ray therapy.

*'Cancer: An Enquiry into the Extent to which Patients receive Treatment." Reports on Public Health and Medical Subjects, No. 89 (H.M. Stationery Office.) 